\title{
"Working capital management and bank performance: empirical research of ten deposit money banks in Nigeria"
}

\begin{tabular}{|c|c|}
\hline \multirow{6}{*}{ AUTHORS } & Osuma Godswill (D https://orcid.org/0000-0001-9242-5265 \\
\hline & Ikpefan Ailemen \\
\hline & Romanus Osabohien (D https://orcid.org/0000-0003-4359-1368 \\
\hline & $\mathbb{R}$ http://www.researcherid.com/rid/R-2284-2019 \\
\hline & Ndigwe Chisom (Dttps://orcid.org/0000-0002-0514-5378 \\
\hline & Nkwodimmah Pascal (D https://orcid.org/0000-0001-9706-6441 \\
\hline ARTICLE INFO & $\begin{array}{l}\text { Osuma Godswill, lkpefan Ailemen, Romanus Osabohien, Ndigwe Chisom and } \\
\text { Nkwodimmah Pascal (2018). Working capital management and bank } \\
\text { performance: empirical research of ten deposit money banks in Nigeria. Banks } \\
\text { and Bank Systems, 13(2), 49-61. doi:10.21511/bbs.13(2).2018.05 }\end{array}$ \\
\hline DOI & http://dx.doi.org/10.21511/bbs.13(2).2018.05 \\
\hline RELEASED ON & Monday, 18 June 2018 \\
\hline RECEIVED ON & Tuesday, 06 February 2018 \\
\hline \multirow[t]{2}{*}{ ACCEPTED ON } & Friday, 11 May 2018 \\
\hline & $((c))_{\text {EY-NC }}$ \\
\hline LICENSE & $\begin{array}{l}\text { This work is licensed under a Creative Commons Attribution-NonCommercial } 4.0 \\
\text { International License }\end{array}$ \\
\hline JOURNAL & "Banks and Bank Systems" \\
\hline ISSN PRINT & $1816-7403$ \\
\hline ISSN ONLINE & $1991-7074$ \\
\hline PUBLISHER & LLC "Consulting Publishing Company "Business Perspectives" \\
\hline FOUNDER & LLC "Consulting Publishing Company "Business Perspectives" \\
\hline
\end{tabular}

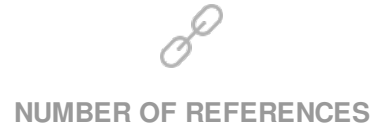

39
NUMBER OF FIGURES

0
NUMBER OF TABLES

5

(C) The author(s) 2022. This publication is an open access article. 


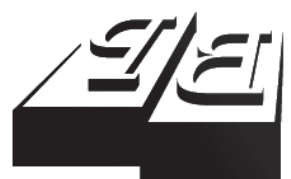

BUSINESS PERSPECTIVES

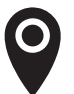

LLC "CPC "Business Perspectives" Hryhorii Skovoroda lane, 10, Sumy, 40022, Ukraine

www.businessperspectives.org

Received on: $6^{\text {th }}$ of February, 2018 Accepted on: $11^{\text {th }}$ of May, 2018

(C) Osuma Godswill, Ikpefan Ailemen, Romanus Osabohien, Ndigwe Chisom, Nkwodimmah Pascal, 2018

Osuma Godswill, Postgraduate Student and Graduate Assistant in the Department of Banking and Finance, Covenant University, Nigeria.

Ikpefan Ailemen, Professor, Department of Banking and Finance, Covenant University, Nigeria.

Romanus Osabohien, Postgraduate Student and Assistant Lecturer in the Department of Economics, Covenant University, Nigeria.

Ndigwe Chisom, Postgraduate Student and Graduate Assistant in the Department of Banking and Finance, Covenant University, Nigeria.

Nkwodimmah Pascal, Postgraduate Student in the Department of Banking and Finance, Covenant University, Nigeria.

\section{(ㄷ)(1) $(8)$}

This is an Open Access article, distributed under the terms of the Creative Commons Attribution-NonCommercial 4.0 International license, which permits re-use, distribution, and reproduction, provided the materials aren't used for commercial purposes and the original work is properly cited.
Osuma Godswill (Nigeria), Ikpefan Ailemen (Nigeria), Romanus Osabohien (Nigeria), Ndigwe Chisom (Nigeria), Nkwodimmah Pascal (Nigeria)

\section{WORKING CAPITAL} MANAGEMENT AND BANK PERFORMANCE: EMPIRICAL RESEARCH OF TEN DEPOSIT MONEY BANKS IN NIGERIA

\begin{abstract}
Working capital management is germane for the success of the banking industry in Nigeria, especially the current state of the sector, which is engulfed with the effect of the global decline in oil price that has resulted in non-performing loans, deterioration of the bank asset quality, laying-off of staff amongst others. This is one of the reasons why the profitability of the banking sector deeply depends on the efficient management of a bank's working capital. Therefore, the objective of this study is to examine how profitability of banks can be enhanced through the working capital management. To empirically carry out the analysis, panel data which consist of ten (10) deposit money banks in Nigeria for seven years (2010-2016) employing the panel fixed effect, panel random effect and the pooled OLS for the two models, which were used as proxies for bank profitability, which includes return on asset (ROA) and return on equity (ROE) to examine the best measure for bank profitability, with the indicators of working capital; net interest income, current ratio, profit after tax, and monetary policy rate. Results of the study showed that working capital management has a significant effect on the profitability of the selected banks and that return on asset is a better measure for bank profitability. Therefore, the study recommends that there should be a periodic review of the minimum capital base of the Nigerian deposit money banks so as to mitigate the effects of inflation and inculcate the consequence of time value of money, because the purchasing power of one (\#1) naira or one (\$1) dollar today would not be sufficient to purchase what it can purchase today for tomorrow.
\end{abstract}

\section{Keywords}

banking industry, return on asset, return on equity, bank profitability

\section{JEL Classification G21, G32}

\section{INTRODUCTION}

A sound, viable and competent banking sector is essential for a stable macroeconomic environment, therefore, the importance of deposit money banks in a country cannot be overemphasized, because they occupy key financial positions in a country and are essential agents that would lead to the growth and development of any economy (Oloye \& Osuma, 2015). The financial manager takes three key financial decisions in an organization including the bank. These decisions include: finance decision, dividend decision and investment decision where the financing decision is the most primary amongst these three.

Therefore, bank managers are usually at a dilemma on how to balance shareholders who are stringent on profitability, which has to do with their dividends, and depositors who are also stringent with liquidity, which has to do with their demand deposits and term deposit as the case may be. This is why effective management of a bank working capital is highly imperative in corporate financial management, because it deals directly 
with the liquidity and profitability of deposit money banks. Thus, working capital is defined mathematically as the difference between current assets and current liabilities, which is a measure of a financial institution well-being. Working capital management also meets the short-term financial obligation of a firm. Working capital of a bank simply represents the operating liquidity available to run the bank on a daily business basis.

Therefore, the efficient management of a bank's working capital can produce benefits such as: maintaining a high level of customers' confidence, enhancing the payment of short-term obligations, growth of the sector, which would contribute its quota immensely to the development of any nation, etc. Working capital is highly imperative to maintaining the solvency, liquidity, survival, and profitability of a firm (Hoque et al., 2015). Yahaya and Bala (2015) also stated that ineffective working capital management reduces profitability and may also lead to the financial crises of an organization which negates what Umoren and Udo (2015) posited that profitability is a yardstick to measuring the operating efficiency of a firm, but amongst the varying factors affecting bank performance, ineffective working capital management was not considered as one of them. In time past, the Nigerian banking sector has witnessed deposit money banks inability to meet up obligations of customers due to inadequate liquidity. This has led to the central bank of Nigeria (CBN) to take part in the management of deposit money banks such as Main-street bank, Spring bank and even Skye bank as at the fourth quarter of 2016. In 2008, CBN gave out bailout funds to some banks because of their high-level non-performing accounts and they could not meet up demands of customers and also satisfy shareholders demand dividend.

It is against this background that this paper seeks to examine profitability and the working capital position at the selected deposit money banks. The article is structured as follows. The next section discusses the conceptual, theoretical framework and empirical literature review, followed by discussing briefly the methodology. Later on, the analysis and discussions on working capital and profitability of the selected deposit money banks in Nigeria are provided. Thus, the article ends with conclusion and recommendation.

\section{LITERATURE REVIEW}

\subsection{Conceptual framework}

The management of working capital has a lot of roles to play in liquidity of banks and other enterprises. According to Smith (1980), working capital management plays germane roles in a firm's profitability and risk management, as well as its value as cited in Adagye (2015). The terms of working capital management (WCM) and management of working capital (MWC) can be used interchangeably. Aborode (2005) opined that working capital management is the balancing of the liquidity and profitability objectives of the firm, as well as taking cognizance of risk as cited in Umoren and Udo (2015). Management of working capital (MWC) is concerned with the differences that arise in the management of current assets, current liabilities and the interrelationships that exist between them. Umoren and Udo (2015) further define the management of working capital (MWC) as all management actions and decisions that ordinarily influence the size and effectiveness of the working capital.
Therefore, the aim of working capital is to optimally manage current assets and current liabilities such that an acceptable level of net-working capital can be achieved. Thus, net working capital (NWC) is the mathematical difference between current assets and current liabilities of an organization. If a firm cannot maintain a satisfactory level of net working capital, it would be insolvent and if not corrected would be commensurate with bankruptcy. Pandey (2010) posited that working capital has two concepts, namely gross working capital and net working capital. He further opined that gross working capital covers the current assets, while the networking capital refers to the difference between a firm's current assets and current liabilities. Working capital refers to the firm's investment in two types of assets, an enterprise investment in current assets needed to operate over a normal business cycle, and enterprise investment in nonfixed assets (Bevan \& Danbolt, 2002; Sogorb-Mira, 2005) as cited in Mbawuni et al. (2016).

AlShubiri (2011) defined working capital as the amount of a business current assets that are being 
financed by long-term debts and/or equity. Padachi et al. (2012) also defined working capital as the lifeblood of a business, and its effective provisioning can do much to ensure the success of the business, the downfall of the enterprise can be linked to neglect an inefficient management. Taking an inference from the aforementioned definitions, working capital can be defined as the professional conscious practice of maintaining an excess of current assets over current liabilities to maintain a good current ratio, which is a basic measure for firm's overall liquidity. Thus, Lovy (2016) defined liquidity as the guarantee that funds will be available quickly to cover all cash outflow commitments in a timely manner. Lovy further deduced an inference from the definition that easily convertible assets are kept in anticipation for customers' demand in terms of demand deposits. Organizations should formulate clear-cut policies relating to the management of the various components of their working capital. Basically, the decisions that are likely to increase a firm's performance tend to raise its risks and vice versa. Profitability indicators are a common proxy for measuring performance and as such Van Horne and Wachowicz (2004) explained two basic principles in finance: firstly, profitability varies inversely with liquidity, which means that an increase in profitability would lead to a decrease in liquidity, and secondly, profitability and risk are proportionately related, that is to attain a higher level of profit a greater risk needs to be taken, while low profit connotes low risk.

\subsection{Strategies of working capital management}

There are three major strategies for working capital management, which are discussed below.

- Aggressive strategy: Profitability is the main focus of this strategy, thus, it is characterized by high risk and high profitability (return) as the case may be. Aggressive strategies involve long-term funds, which are utilized only to finance fixed assets and part of permanent working capital, while short-term funds are utilized to finance temporary working capital. It saves the interest cost at the cost of high risk.

- Conservative strategy: This strategy involves low risk and profitability. In most cases, it is termed a risk-free approach to working capital financing. Working capital here is financed by long-term sources of funds such as term loans, equities, etc.

- Hedging/Marching strategy: This strategy can also be termed the hedging strategy and it involves an equal level of risk for the same level of return/profitability, i.e. in this strategy, each asset would be financed by a debt instrument of almost the same maturity.

\subsection{Empirical framework}

Umoren and Udo (2015) examined the effects of working capital management on the profitability and liquidity of selected deposit money banks using descriptive statistics, regression and Pearson's correlation coefficients. It was found that there is a significant positive relationship between bank performance and bank size; there is a significant negative relationship between profitability and cash conversion cycle, which supports the findings of Yeboah and Yeboah (2014). Shin and Soenen (1998) and Deloof (2003) found that profitability and risk-adjusted returns are inversely related to the cash conversion cycle, further suggesting that aggressive working capital policy improves firm performance as cited in ALShubiri (2011). Hoque et al. (2015) examined working capital management and profitability in a cement industry of Bangladesh and revealed that profitability position and working capital position over the period under study were not satisfactory. Bandara (2015) also examined the impact of working capital management policy on market value addition in Sri Lankan companies. Descriptive statistics, correlation and panel regression analysis were adopted as the tool for measurement and analysis. According to the overall panel regression model, working capital investment policy and working capital financing policy both recorded a negative relationship to market value addition.

Afza and Nazir (2008) analyzed the impact of various types of working capital management policies on financial performance and found that there were two types of working capital policy, namely conservative and aggressive working capital. They used a sample of 263 non-financial firms from 17 different sectors. The result showed that there was an inverse relationship between the degree of 
aggressiveness of these policies and profitability. Ogodor and Mukolu (2015) worked on working capital adequacy and organization performance. They chose First Bank Nigeria Plc and Guaranty Trust Bank Plc for their analysis using ordinary least square (OLS) as its estimation technique and the result of their findings revealed that working capital management did have a significant impact on bank performance during the period under review.

Mandiefe (2016) investigated the effect of working capital management on the profitability of Afriland First Bank Cameroon using a twelve-year time series data (2002-2013), which was extracted from the bank's financial statement. Thus, using correlation and ordinary least square for the analysis, the result of the analysis showed that working capital management influenced the Afriland First Bank of Cameroon. Charitou et al. (2010) examined the effect of working capital management on the financial performance of firms in emerging markets. The data set used consisted of firms listed on the Cyprus Stock Exchange for the period 1998-2007 using multivariate analysis and found out that cash conversion cycle and creditors payment period are associated with the firm's profitability. It was further acclaimed that the study would be of immense importance to managers, investors, creditors and financial analysts especially after the recent global financial crisis as cited in Ogodor and Mukolu (2015).

Ghosh and Maji (2004) examined the efficiency of working capital management in Indian cement companies between the years 1992 to 1993 and 2001 to 2002 to measure the efficiency of working capital management, its performance, and utilization. The overall efficiency indices were calculated instead of using the common working capital management ratios. The authors also examined the pace required to achieve the target level of efficiency by an individual company during the period under study. It was empirically found that the cement industry in India did not perform remarkably well during the periods under review. Brigham (2004) also examined the effect of working capital management on the profitability of Indian firms with the use of the ordinary least square (OLS). The study revealed that working capital management and portability are positively correlated in Indian companies as cited in Mandiefe (2016). Sharma and Kumar (2011) conducted a similar study in Indian companies which concord with the results of Brigham (2004). The study by Sharma and Kumar (2011) found that working capital management (WCM) and profitability are positively correlated in Indian companies.

Rahemen and Nasr (2007) studied the relationship between working capital management and corporate profitability for ninety-four (94) firms listed on Karachi Stock Exchange using a static measure of liquidity and operating measure of working capital between the years 1999-2004. The study found a negative relationship between profitability and working capital management measures. Alvarez (2001) examined the relationship between working capital management and corporate profitability of firms making use of a hundred and one (101) companies listed on Tehran Stock Exchange (TSE) between the years 2004-2008 using multivariate regression and Pearson correlation. The study found out that cash conversion cycle had a positive relationship with corporate profitability as cited in Mandiefe (2016). To sum it up, most of the studies reviewed show that working capital management plays a significant role in the success of any enterprise due to its positive effect on profitability and liquidity.

\subsection{Oil price decline and sectoral performance}

Poghosyan and Hesse (2009) examined oil prices and bank profitability taking a clue from major oil-exporting countries in Middle East and North Africa. Data from a hundred and forty-five (145) banks in eleven (11) Middle East and North African oil exporting countries between 1994-2008 was analyzed. The authors found that oil price volatility had an indirect effect on bank profitability and investment banks appeared to be more affected by the oil price shocks when compared to Islamic banking and commercial banks, thereby depleting their working capital.

Monaldi (2015) posited that since June 2014, which was the beginning of the oil price decline globally, many oil exporting nations have been affected, and Venezuela stood out as one of the hardest hit 
amongst other countries. He concluded that the macroeconomic crisis would worsen in Venezuela due to lack of economic adjustments in an election year and the foresee able future does not look appealing for Venezuela.

Khandelwal et al. (2016) studied the impact of oil prices on the banking system in the GCC (Gulf Cooperation Council) by examining the link between the oil price movement, macroeconomics and financial development in the GCC. They used a multivariate panel approach and an auto-regressive approach for the analysis and found that there existed a strong empirical evidence of feedback loops between oil price movements, bank balance sheets, and asset prices.

Liu and Ma (2016) examined the impact of low oil price on China and the world natural gas industry chain, which housed a comparative analysis of the natural gas industry chain experience from high oil price periods to low oil price periods. The authors concluded that the declined oil price has led to business performance decline especially in the oil and gas companies. They further stated that all these companies cut down their capital expenditure. They also stated that declined oil prices have led to a decrease in the prices of natural gas to different extent globally. Lawal et al. (2017) posited that decrease in the external debt of a country eventually draws investors to invest in a country due to better economic performance. And for expatriates to undergo businesses in a country the services of deposit money banks would be very essential in the payment procedures, thereby increasing the working capital positions of the indigenous banks.

\section{METHODOLOGY}

This study is built on the anticipated income theory, which states that a term loan repayment should be tied to the borrower income. In such a scenario, the borrower's is usually a customer of the bank and the bank may have reviewed the customer's loan application ensuring that the income of the customer would match the loan needed usually to be covered in full within a year or two. In this theory, collateral is not usually used in the recovery of both interest and principal amount, but the fu- ture/projected income is preferred to meet its obligation and ensure adequate liquidity. Banks usually liquidate term loans not by the selling collateral asset or goods of the borrower as in the case of the commercial loan theory but by the anticipated income of the borrower. In using this approach, the bank ensures that it has sufficient working capital to run its business.

\subsection{Model specification}

Thus, the model as adopted from Yeboah and Yeboah (2014) is specified as follows:

$$
b P_{t}=\beta_{0}+\sum_{t=1}^{n} \beta X+e,
$$

where $b P_{t}$ is bank profitability proxied by return on equity and return on asset; $\beta$ is a constant; $X$ profit after tax, current ratio, net interest income, and monetary policy rate. The variables in this model were adopted from the empirical work by Yeboah and Yeboah (2014).

The implicit form of equation (1) is represented in equation (2), while the explicit form is represented in equations (3) and (4) for return on asset and return on equity, respectively, as proxies for bank profitability:

$$
b P=f(\text { pat, } c r, \text { nii, } m p r) .
$$

Equation (2) is the bank profitability equation, which is the combination of return on asset (roa) and return on equity (roe) and is specified separately in equations (3) and (4):

$$
\begin{aligned}
& \operatorname{roa}_{i t}=\alpha_{0}+\alpha_{1} \text { pat }_{i t}+\alpha_{2} c r_{i t}+ \\
& +\alpha_{3} \operatorname{nii}_{i t}+\alpha_{4} \text { mpr }_{i t}+\mu_{i t}, \\
& \operatorname{roe}_{i t}=\alpha_{0}+\alpha_{1} \text { pat }_{i t}+\alpha_{2} \text { cr }_{i t}+ \\
& +\alpha_{3} \operatorname{nii}_{i t}+\alpha_{4} \text { mpr }_{i t}+\mu_{i t} .
\end{aligned}
$$

$\left\{p a t_{i t}, c r_{i t}, n i i_{i t}, m p r_{i t}\right\} i^{N}=1$ e.i.d (exogenous and identically distributed). The idiosyncratic disturbance term $u_{i t}$ is assumed to be serially not correlated with the independent variables of the past, present and future time periods of the entities. This is a strong assumption which is to eliminate lagged endogenous variable. Also, it is assumed 
that the idiosyncratic disturbance term is not correlated with the entity specific effect. Entity in this study is referred to as bank. The error variance is the mean squared error, which represents the unbiased estimate of error variance in the regression. It helps to test the violation of OLS assumptions in a given regression model which is shown below:

$V\left[\mu_{i} \mid\right.$ pat $_{i t}, c r_{i t}, n i i_{i t}$, mpr $\left._{i t}\right]=v_{i t}^{2} 1, v_{i t}^{2}>0$ and finite and, (homoscedasticity and no serial correlation),

$V\left[\mu_{i} \mid\right.$ pat $\left._{i t}, c r_{i t}, n i i_{i t}, m p r_{i t}\right]=v^{2}{ }_{i t} 1, v_{i t}^{2}>0$ finite and $\operatorname{cov}\left[\mu_{i t}, \mu_{i t} \mid p a t_{i t}, c r_{i t}, n i i_{i t}\right.$, mpr $\left._{i t}\right]=0$ (no serial correlation),

$V\left[\mu_{i} \mid\right.$ pat $_{i t}, c r_{i t}, n i i_{i t}$, mpr $\left._{i t}\right]=$

$=\Omega u, I\left(\right.$ pat $_{i t}, c r_{i t}$, nii $_{i t}$, mpr $\left._{i t}\right)$

independent and no multicollinearity.

The above OLS violation assumptions (no multicollinearity, no serial correlation, no heteroscedasticity or assumption of equal variance) will be tested in the third section to show that those assumptions are not violated and to avoid spurious results. The observations are exogenous across entities (banks), but not necessarily across time. This is guaranteed by random sampling of entities for this study.

As earlier defined, $b p$ is bank profitability, proxied by return on asset (roa) and return on equity (roe) see equations (3) and (4) pat is profit after tax; $c r$ is current ratio; nii is net interest income; and $m p r$ is monetary policy rate (see Tables 1-3); $\alpha_{0}$ is the constant term; $\alpha_{1}, \alpha_{2}, \alpha_{3}, \alpha_{4}$ are the coefficients of the exogenous variables; $i$ and $t$ represent banks and years under review. $\mu$ is the error term which captures other exogenous variables that are not specified in the model.

The assumption about the error term is that it helps to predict the nature of the regression model that is: whether the model is referring to the random effects or fixed effects (Hsiao et al. 1999). In a fixed effect regression model, $\mu_{i t}$ is presumed to be nonstochastically over $i$ and/or $t$ making the fixed effect model analog to a dummy variable model in one dimension. In a random-effects model, $\mu_{i t}$ is assumed to stochastically vary over $i$ or $t$ requiring special treatment of the error variance (Hsiao et al., 1999).
Thus, it is expected that $\beta>i=1,2,3$, while, $\beta_{4}<0$. All things being equal, the a priori expectation is that an increase in profit after tax, current ratio, net interest income increases banks profitability, while monetary policy rate has an inverse relationship with bank profitability.

The study adopts the pooled OLS (the combination of fixed effect and random effect panel model) to examine the influence of working capital on ten deposit money banks (Guarantee Trust bank, Fidelity bank, Access bank, Zenith bank, First bank, Diamond bank, Skye bank, Wema bank, Sterling bank, and UBA) profitability in Nigeria for the selected period. The formulation of a fixed effect model brings to bear the divergences across banks, which are captured in differences in the constant term (Greene, 2008).

As stated earlier, the general objective of this research is to examine profitability and the working capital position of ten deposit money banks in Nigeria. The study engaged the pooled ordinary least square (POLS). The pooled OLS estimator ignores the panel structure of the data and simply estimates $\beta$ as;

The random effects estimator is the feasible generalized least squares (GLS) estimator;

where $W=\left[i_{N T} X Z\right]$ is a vector of one component. The error covariance matrix $\Omega v$ is assumed block-diagonal with equi-correlated diagonal element

$$
\delta u^{2}=\frac{1}{N t-1} \sum_{t=0}^{T} \sum_{i=0}^{T} \delta u_{i t}{ }^{2},\left(\delta c^{2}=\delta u^{2}-\delta u^{2}\right)
$$

where

$$
\delta_{i t}=y_{i t}-\beta P O L S \text { and } \delta u^{2}=\sum_{(t=0)}^{T} \sum_{(i=0)}^{T} \delta u^{2} .
$$

The degree of freedom correction in $\delta u^{2}$ is also asymptotically necessary when $N \leftrightarrow \infty$.

The fixed effect within the model estimator of the slope coefficient $\beta$ estimates within the model

$$
\beta_{F E}=(\ddot{X} \ddot{x})^{-1} \ddot{x}^{\prime} y \text {. }
$$


Table 1. Data source

Source: Compiled by the authors.

\begin{tabular}{|c|c|c|c|}
\hline Variable name & Identifier & Source of data & Definition and measurement \\
\hline Profit after tax & pat & $\begin{array}{l}\text { Banks financial } \\
\text { statement }\end{array}$ & $\begin{array}{l}\text { Profit after tax is defined as the profit earned by the bank after all forms of } \\
\text { financial deductions have been made, such deduction may include taxation. } \\
\text { It is a measure of financial health and strength of an organization }\end{array}$ \\
\hline Current ratio & $\mathrm{Cr}$ & $\begin{array}{l}\text { Banks financial } \\
\text { statement }\end{array}$ & $\begin{array}{l}\text { Current ratio is defined as a liquidity ratio that measures a company's ability } \\
\text { to pay short-term and long-term obligations. It is computed by dividing } \\
\text { current asset by current liabilities }\end{array}$ \\
\hline $\begin{array}{l}\text { Net interest } \\
\text { income }\end{array}$ & nii & $\begin{array}{l}\text { Banks financial } \\
\text { statement }\end{array}$ & $\begin{array}{l}\text { This is defined as the mathematical difference between revenue bearing } \\
\text { assets and the cost of serving the interest burdened liabilities. It is usually } \\
\text { included in the income statement in the bank balance sheet }\end{array}$ \\
\hline Return on asset & roa & $\begin{array}{l}\text { Banks financial } \\
\text { statement }\end{array}$ & $\begin{array}{l}\text { This is a profitability indicator of how profitable a firm is in relation to its } \\
\text { total assets. It is usually computed in percentages. It is calculated as net } \\
\text { income divided by the firm's total assets }\end{array}$ \\
\hline Return on equity & roe & $\begin{array}{l}\text { Banks financial } \\
\text { statement }\end{array}$ & $\begin{array}{l}\text { This is also a profitability indicator of how it is the amount of net income } \\
\text { returned as shareholder equity. It is calculated by dividing net income by } \\
\text { shareholder equity }\end{array}$ \\
\hline $\begin{array}{l}\text { Monetary policy } \\
\text { rate }\end{array}$ & $m p r$ & $\begin{array}{l}\text { World } \\
\text { development } \\
\text { indicators }\end{array}$ & $\begin{array}{l}\text { This rate is usually stipulated by the Central Bank of Nigeria (CBN) to the } \\
\text { deposit money bank. This is the interest rate at which CBN lends to deposit } \\
\text { money banks and other clients }\end{array}$ \\
\hline
\end{tabular}

\subsection{Data source and sample size}

Data was derived from the annual financial statements of the selected Nigerian banks for the corresponding years and the world development indicator (WDI) of the World Bank for the period under study (2010-2016). The sample population is the deposit money banks that exist in the Nigerian banking sector. This study is conducted using the simple random sampling technique of probability sampling and ten (10) banks, which make up the sample size (Guarantee Trust bank, Fidelity bank, Access bank, Zenith bank, First bank, Diamond bank, Skye bank, Wema bank, Sterling bank and UBA), were selected and engaged as the sample. Six variables were engaged in the analysis: return on assets and return on equity are as indicators of bank profitability, while profit after tax, net interest income, current ratio and monetary policy rate are the independent variables, which are presented in Table 1.

\section{PRESENTATION AND DISCUSSION OF RESULTS}

\subsection{Presentation of results}

The starting point of the analysis is to first, determine the summary statistics of the selected variables which is presented in Table 2 .
Table 2. Summary statistics of variables

Source: Authors' compilation

\begin{tabular}{l|c|c|c|c}
\hline Variable & Mean & $\begin{array}{c}\text { Standard } \\
\text { deviation }\end{array}$ & Minimum & Maximum \\
\hline roa & 2.2891 & 2.025815 & -4 & 7.5 \\
\hdashline roe & 11.58306 & 25.49299 & -150.64 & 37.1 \\
\hdashline pat & 2.6207 & 3.1507 & -5.7707 & 1.2708 \\
\hdashline cr & 1.198673 & .3652923 & 0.3 & 4 \\
\hdashline nii & 7.3707 & 6.2207 & 2.952 & 2.6008 \\
\hdashline mpr & 10.302 & 2.266095 & 6.08 & 12.8 \\
\hline
\end{tabular}

Table 2 presents the descriptive or summary statistics of the variables employed in the model. The descriptive statistics shows the trend and comprehensive evidence about the variables. Therefore, it demonstrates the average and standard deviation of the different variables of interest in the study (Yeboah \& Yeboah, 2014). Also, the minimum and the maximum value of the variables are presented in the descriptive statistics of the variables. The mean of return on asset (ROA) is 2.289 and it ranges from -4 to 7.5 ; the mean of return on equity $(R O E)$ is 11.58 and it ranges from 150 to 37 ; the mean of profit after tax (pat) is 2.62 and it ranges from negative -5.77 to 1.27 ; the mean value of current ratio $(c r)$ is approximately 1.199 and it ranges from 0.3 to 4 ; the mean value of net interest income (nii) is 7.34 and it ranges from 2.952 to 2.60; and monetary policy rate $(m p r)$ has a mean value of 10.30 and ranges from 6.08 to 12.8 , respectively. 
Table 3. Regression model estimates

Source: Authors' compilation.

\begin{tabular}{|c|c|c|c|c|c|c|c|}
\hline \multicolumn{4}{|c|}{ Return on asset model } & \multicolumn{4}{|c|}{ Return on equity model } \\
\hline \multicolumn{4}{|c|}{ Panel fixed effect regression } & \multicolumn{4}{|c|}{ Panel fixed effect regression } \\
\hline Variable & Coef. & Std. error & P-value & Variable & Coef. & Std. error & P-value \\
\hline pat & 3.4808 & 9.0809 & $0.000^{*}$ & pat & -0.57465 & 1.83686 & 0.755 \\
\hline $\mathrm{Cr}$ & -0.2838 & 0.4564 & $0.0536^{* * *}$ & $\mathrm{Cr}$ & -5.6123 & 5.187729 & $0.0283^{* *}$ \\
\hline$n i i$ & -4.8109 & 3.9509 & 0.227 & $n i i$ & 2.5308 & 4.2608 & $0.0555^{* *}$ \\
\hline$m p r$ & -0.1817 & 0.0847 & 0.035 & $m p r$ & 2.4905 & 0.8846 & $0.006^{*}$ \\
\hline const & 3.9379 & 0.9116 & $0.000^{*}$ & const & 2.984288 & 29.24661 & 0.919 \\
\hline
\end{tabular}

Panel random effect regression

Panel random effect regression

\begin{tabular}{|c|c|c|c|c|c|c|c|}
\hline Variable & Coef. & Std. error & P-value & Variable & Coef. & Std. error & P-value \\
\hline pat & 4.6408 & 7.2209 & $0.000^{*}$ & pat & 2.309753 & 1.6495 & 0.161 \\
\hline $\mathrm{Cr}$ & -0.00418 & 0.4528 & $0.00^{*}$ & $\mathrm{Cr}$ & -4.52009 & 5.31971 & 0.395 \\
\hline nii & -4.009 & 3.4309 & $0.0236^{* *}$ & $n i i$ & 5.2308 & 3.7108 & $0.0158^{* *}$ \\
\hline$m p r$ & -0.25356 & .0795293 & $0.001 *$ & $m p r$ & 1.826448 & 0.8915 & $0.041 *$ \\
\hline const & 3.9799 & 0.92067 & $0.000^{*}$ & const & -41.51192 & 26.5032 & $0.0117^{* *}$ \\
\hline \multicolumn{4}{|c|}{ Estimates from POOLED OLS } & \multicolumn{4}{|c|}{ Estimates from POOLED OLS } \\
\hline Variable & Coef. & Std. error & P-value & Variable & Coef. & Std. error & P-value \\
\hline pat & 4.7908 & 7.0109 & $0.000 *$ & pat & 3.272655 & 1.6020 & $0.044^{* *}$ \\
\hline $\mathrm{Cr}$ & 0.0650 & 0.4560 & 0.887 & $\mathrm{Cr}$ & -3.8437 & 5.4436 & $0.048^{* *}$ \\
\hline nii & -4.2009 & 3.3609 & $0.0215 * *$ & nii & 4.9008 & 3.5408 & $0.070^{* * *}$ \\
\hline$m p r$ & -0.2622 & 0.07995 & $0.001 *$ & $m p r$ & 1.6435 & 0.9158 & $0.076^{* *}$ \\
\hline const & 3.96045 & 0.9276 & $0.000^{*}$ & const & 5.725 & 2.8115 & $0.034^{* *}$ \\
\hline
\end{tabular}

Hausman test

Test: H0: difference in coefficients is not systematic

Prob. $>$ chi $2=0.0064$

Note: ${ }^{*}, * *, * *$ mean statistically significant at $1 \%, 5 \%$ and $10 \%$, respectively. Coef. means coefficient; Std. error means standard error, $\mathrm{P}$-value means probability values.

Table 3 presents results from the regression model for equations (return on asset and return on equity). From the pooled OLS results for return on assets (Table $3,5^{\text {th }}$ quadrant), it was observed that a unit increase in profit after tax leads to about 4.7908 unit increase in return on asset. With the probability value of 0.000 , it could be inferred that profit after tax is statistically significant to the model at $1 \%$ level. If current ratio increases by $1 \%$, return on asset increases by $6.5 \%$. Also, net interest income and current ratio are statistically significant to the model. As could be seen, a unit changes in net interest income lead to a decrease in return on asset by 4.2 units. Thus, an ineffective monetary policy has the potential of decreasing return on asset by $22.6 \%$. In this wise, other policies such as macro prudential policies and social protection policies will enhance the efficacy of the financial sector that will aid bank profitability.
As pointed earlier, the starting point of this study is to measure bank profitability using two main indicators, return on asset (roa) and return on equity (roe), to know the better measurement of bank profitability. Table 3 ( $6^{\text {th }}$ quadrant) presents the estimated output from pooled OLS results for return on equity. From the table, a unit increase in profit after tax leads to about 3.27 unit increase in return on equity. With the probability value of 0.044 , it means that profit after tax is statistically significant to the model at $5 \%$ level. If current ratio increases by 1 unit, return on asset decreases by 3.84 units. Net interest income increases return on equity by approximately 4.9 units, monetary policy rate increases return on equity by 1.6 units. It can be concluded that jointly the variables are statistically significant in both the return on asset model and return on equity model. 
From the Return on Asset (roa) Fixed regression model (Table 3, $1^{\text {st }}$ quadrant), it was observed that a unit increase in profit after tax leads to about 3.48 unit increase in return on asset. An increase in current ratio reduces return on asset by approximately 0.28 . If net interest income increases by 1 unit, return on asset decreases by 4.81 units. In a similar vein, monetary policy rate reduces return on asset approximately by 0.18 . Given the probability value (Prob. $=0.0634)$, it shows that jointly the variables are significant explanatory factors of return on asset. Estimated result obtained from the fixed effect panel regression for return on equity is present in the $2^{\text {nd }}$ quadrant in Table 3; it shows that unit increase in profit after tax leads to about 0.57 unit decrease in return on equity. This is not statistically significant and against the apriori expectation, as it was expected for profit after tax to enhance bank profitability. If current ratio increases by 1 unit, return on equity decreases by 5.6 units. Net interest income tends to increase return on equity by 2.53 units, monetary policy rate increases return on equity by 2.49 units. Similarly, the estimated result of random effect panel regression for return on asset is presented in the $3^{\text {rd }}$ quadrant of Table 3. From the table, a unit increase in profit after tax leads to 4.64 unit increase in return on asset; a unit increase in current ratio has an infinitesimal decrease on return on asset by 0.004; a unit increase in net interest income leads to a decrease in return on asset by 4.0 units; a unit increase in monetary policy rate decreases return on asset by 0.25 .

The $4^{\text {th }}$ quadrant of Table 3 presents the estimated result of random effect panel regression for return on equity. From the table, a unit increase in profit after tax leads approximately to 2.311 unit increase in return on equity; a unit increase in current ratio decreases return on equity by 4.52 ; a unit in- crease in net interest income leads to an increase in return on equity by 5.23 units; a unit increase in monetary policy rate increases return on equity by approximately 1.83 . To know which of the indicators (either return on asset or return on equity) is better in measuring bank profitability, and what is the best method (panel fixed effect or panel random effect), the Hausman test was conducted. From the Hausman test, the null hypothesis $\left(H_{0}\right)$, which states that the difference in coefficients is not systematic, is accepted. By implication, this means that return on asset is a better measure of banks profitability and the fixed panel effect tends to be the best method.

To show the results obtained are not biased and spurious, diagnostic tests were conducted to ensure the estimate efficiency. The diagnostic tests include: Breusch-Pagan test for heteroscedasticity, Ramsey RESET test for omitted variable, and pairwise correlation matrice for multicollinearity as presented in Tables 4 and 5.

Table 4. Robustness test

Source: Authors compilation

\begin{tabular}{|c|c|c|c|}
\hline \multicolumn{2}{|c|}{ Return on asset model } & \multicolumn{2}{|c|}{ Return on equity model } \\
\hline $\begin{array}{l}\text { Breusch-Pagan test } \\
\text { for heteroscedasticity }\end{array}$ & $\begin{array}{l}\text { Prob. } \\
0.92\end{array}$ & $\begin{array}{l}\text { Breusch-Pagan test } \\
\text { for heteroscedasticity }\end{array}$ & $\begin{array}{l}\text { Prob. } \\
0.91\end{array}$ \\
\hline $\begin{array}{l}\text { Ramsey RESET test } \\
\text { for omitted variable }\end{array}$ & $\begin{array}{l}\text { Prob. } \\
0.52\end{array}$ & $\begin{array}{l}\text { Ramsey RESET test } \\
\text { for omitted variable }\end{array}$ & $\begin{array}{l}\text { Prob. } \\
0.75\end{array}$ \\
\hline
\end{tabular}

Table 4 presents the Breusch-Pagan test for heteroscedasticity and the Ramsey RESET test for omitted variable bias for both models. Since the probability values of $0.92,0.52,0.9$, and 0.75 are statistically not significant, it means that the model satisfies the assumption of homoscedasticity and the variables are correctly specified. The variance inflation factor test for multicollinearity is presented in Table 5.

Table 5. Correlation test for multicollinearity

Source: Authors compilation.

\begin{tabular}{|c|c|c|c|c|c|c|}
\hline & roa & roe & pat & $\mathbf{C r}$ & nii & mpr \\
\hline roa & 1.0000 & & & & & \\
\hline roe & 0.3186 & 1.0000 & & & & \\
\hline pat & 0.5594 & 0.3819 & 1.0000 & & & \\
\hline $\mathrm{Cr}$ & 0.0530 & 0.0496 & 0.1301 & 1.0000 & & \\
\hline nii & 0.2792 & 0.3008 & 0.6157 & 0.1336 & 1.0000 & \\
\hline$m p r$ & -0.0270 & 0.1848 & 0.3875 & 0.1339 & 0.1854 & 1.0000 \\
\hline
\end{tabular}


The correlation matrix as presented in Table 5 shows the relationship between variables selected for this study. The most common correlation coefficient is Pearson's correlation coefficient, which was used in this study to determine the presence or absence of multicollinearity among the variables. It compares two ratio variables, and most times, the main diagonal of the correlation matrix table is a set of ones, because the correlation between a variable and itself is always 1 . In other words, a correlation matrix is also a symmetric matrix. In a nutshell, as seen in Table 5, the variables exhibit no incidence of multicollinearity as the coefficients are less than 0.8 .

\subsection{Results and discussion}

This section discusses the estimated results from the regression model. The estimated result for this study is similar to the results obtained by the study by Mandiefe (2016), who also used the panel ordinary least squares. The study found that working capital management influenced performance of Afriland First Bank in Cameroon. This argument is validated by the pooled OLS estimated results in Table 3: an increase in profit after tax increases return on asset by 3.48 units, but poses a reduction of 0.57 units on equity. Similarly, effective monetary policy enhances the profitability of banks by 2.49 units, while weak monetary policy rates reduce banks profitability by 18.17 units. Current ratio tends to reduce return on asset by 0.28 and return on equity by 5.6 units. The rationale behind this negative relationship could be the bank inability to pay its short-term and long-term obligations promptly.

The findings also support Umoren and Udo (2015), who examined the effects of working capital management on the profitability and liquidity of selected deposit money banks using Pearson correlation matrix to determine the level of the incidence of multicollinearity. This study also aligns with Umoren and Udo (2015) as it was observed in the study that the model exhibits no incidence of multicollinearity (see Table 5).

Hoque et al. (2015) carried out a study on management of working capital and profitability in Bangladesh using cement industry and revealed that profitability position and working capital were not satisfactory. This study also confirms the argument of Hoque et al. (2015) as current ratio and net interest income have a negative relationship with return on asset and return on equity. In line with that, Yahaya and Bala (2015) posed that liquidity implied better performance, stating that listed deposit money banks in Nigeria should maintain a higher acid test ratio to increase profitability.

Bandara (2015) also examined the impact of working capital management policy on market value addition in Sri Lankan companies using descriptive statistics, correlation and panel regression analysis. According to the overall panel regression model, working capital, investment policy, and working capital financing policy recorded a negative relationship to market value addition. This study is in disagreement with Afza and Nazir (2008), who argued that there was an inverse relationship between the degree of policies and profitability (Table 3). It can be seen that there exists a positive relationship between monetary policy rates and banks profitability (return on assets and return on equities); this means that weak monetary policy rates in Nigeria reduce banks profitability by approximately 0.18 units, and the strong policy improves banks performance by 2.49 units, respectively, which in turn would commensurate to a higher working capital. This means that effective monetary policy and strong institutional framework will enhance banks performance (Osabohien et al., 2018).

\section{CONCLUSION AND RECOMMENDATION}

The deposit money banks must develop necessary steps to utilize their idle cash and bank balances in order to meet their short-term debt obligations and operating cost thereby improving the current ratio. It was also shown from the analysis that the return on asset (ROA) is a better measure of profitability as obtained from the Hausman test, and fixed panel effect is proven to be a better methodology compared to random panel effect. 
This paper has shown that there is a significant relationship between working capital management and bank profitability from the afore-shown analysis. The corporate restructuring exercise implemented and carried out during 2005 by the CBN governor professor Soludo (2004) has repositioned the deposit money banks but it would be highly imperative for the time value of money to be considered in working capital efficiency. Therefore, there should be a periodic stress test and recapitalization of deposit money banks such that the 25 billion minimum capital requirements should be reviewed at least once in every five years to meet up with the changing time value of money so as to ensure and enable the global competitiveness of the Nigerian deposit money banks.

\section{AREAS FOR FURTHER RESEARCH}

This research work was limited to data from only deposit money banks (DMBs), therefore, other financial institutions such as: insurance companies, microfinance banks, merchant banks, mortgage banks, etc., should be explored in order to ascertain the working capital contribution of the various banks so as to compare and portray a generalized view of the banking sector in Nigeria and to confirm the study result. More indicators and proxies to measure working capital and bank performance need to be explored in order to broaden the horizon of other researchers, who may want to further study some aspects in working capital management. Some observed pitfalls in working capital management for deposit money banks performance need to be addressed in order to prepare the banks for any unforeseen circumstances such as: global oil price decline, international financial crisis (external factors) and some other internal factors, which may hamper the smooth operations of the banks.

\section{ACKNOWLEDGEMENT}

The initial version of this manuscript was presented at the Association of Professional Bankers in Education (APBE) conference by Osuma Godswill at Afe-Babalola University in Nigeria on the $23^{\text {rd }}$ of November, 2017, which corrections were appreciated. We would also want to appreciate Covenant University Center for Research Innovation and Discovery (CUCRID) for the sponsorship of this manuscript.

\section{REFERENCES}

1. Aborode, R. (2005). Strategic financial management (pp. 150-156). Lagos: Masterstroke Consulting.

2. Adagye, I. D. (2015). Effective working capital management and the profitability of quoted banks in Nigeria. European Journal of Accounting Auditing and Finance Research, 3(2), 97-107. Retrieved from http://www.eajournals.org/ wp-content/uploads/EffectiveWorking-Capital-Managementand-the-Profitability-of-QuotedBanks-in-Nigeria.pdf

3. Afza, T., \& Nazir, M. S. (2008), Working Capital Approaches and Firm's Returns in Pakistan.
Pakistan Journal of Commerce and Social Sciences, 1(1), 25-36. Retrieved from http://www.ciitlahore.edu.pk/Papers/Abstracts/146-8589069448170326667. pdf

4. AlShubiri, F. N. (2011). The Effect of Working Capital Practices on Risk Management: Evidence From Jordan. Global Journal of Business Research, 5(1), 39-54. Retrieved from ftp://ftp.repec.org/opt/ReDIF/ RePEc/ibf/gjbres/gjbr-v5n1-2011/ GJBR-V5N1-2011-4.pdf

5. Alvarez, S. A., \& Busenitzs, L. W. (2001). Resource-Based theory. Journal of Management, 6(1), 755-775.
6. Bandara, R. (2015).

Impact of Working Capital

Management Policy on Market

Value Addition. Global Journal of Contemporary

Research in Accounting, Auditing and Business Ethics (GJCRA), 1(2), 354-373. Retrieved from http://globalbizresearch.org/ files/2040_gjcra_rms-bandara-3357.pdf

7. Bevan, A. A., \& Danbolt, J. (2002). Capital structure and its determinants in the UK a decompositional analysis. Applied Financial Economics, 12(3), 159-170. http://dx.doi.org/10.1080/09603100110090073 
8. Brigham, E. F. (2004). Effect of working capital management on the profitability of Indian firms. European Journal of Business and Management, 3(2), 23-27.

9. Charitou, M. S., Elfani, M., \& Lois, P. (2010). The effect of working capital management on firm's profitability: Empirical evidence from an emerging market. Journal of Business and Economic Research, 8(12), 63-68. Retrieved from https://scholar.google.co.za/scholar $? \mathrm{q}=$ Charitou $\% 2 \mathrm{C}+\mathrm{M} . \% 2 \mathrm{C}+\mathrm{S}$.+Elfa $\mathrm{ni} \% 2 \mathrm{C}+\mathrm{M}+$ and + Lois $\% 2 \mathrm{C}+\mathrm{P} .+\& \mathrm{bt}$ $\mathrm{nG}=\& \mathrm{hl}=$ en\&as_sdt $=0 \% 2 \mathrm{C} 5$

10. Deloof, M. (2003). Does Working Capital Management Affect Profitability of Belgian Firms? Journal of Business, Finance and Accounting, 30(4), 573-587.

11. Ghosh, S. K., \& Maji, S. G. (2004). Working capital management efficiency: a study on the Indian cement industry. The Management Accountant, 39(5), 363-372.

12. Greene, W. H. (2008). Econometric analysis (6th ed.). Upper Saddle River, N.J.: Prentice Hall.

13. Hoque, A., Mia, A., \& Anwar, R. (2015). Working Capital Management and Profitability: A Study on Cement Industry in Bangladesh. Research Journal of Finance and Accounting, 6(7), 18-28. Retrieved from http://www. jitbm.com/JITBM\%233036th\%20 Volume/Md\%20Amin7.pdf

14. Hsiao, K., Lahiri, \& Lee, L.-F. (Eds.) (1999). Analysis of Panels and Limited Dependent Variables: A Volume in Honour of G. S. Maddala (338 p.). Cambridge: Cambridge University Press.

15. Ikpefan, A. O., \& Owolabi, F. O. (2014). Working Capital Management and Profitability of the Manufacturing Sector: An Empirical Investigation of Nestle Nigeria PLC and Cadbury Nigeria PLC. Global Journal of Management and Business Research, 14(4), 23-34.

16. Khandelwal, P., Miyajima, K., \& Santos, A. (2016). The impact of oil prices on the banking system in the GCC (IMF Working Paper, 5(WP/16/161), 23). Retrieved from https://www.google.com.kw/ search?q=oil+prices+and+bank+as
sets+GCC\&oq=oil +prices+and + ba nk+assets+GCC\&aqs=chrome..69i 57j015.12351j0j8\&sourceid $=$ chrom e\&ie=UTF-8

17. Lawal, A. I., Kazi, K. P., Adeoti, J. O., Osuma, O. G., Akinmulegun, S. O., \& Ilo, B. (2017). Capital Flight and the Economic Growth: Evidence from Nigeria. Binus Business Review, 8(2), 125. https:// doi.org/10.21512/bbr.v8i2.2090

18. Liu, Y., \& Ma, L. (2016). Impacts of low oil price on China and the world natural gas industry chain. Natural Gas Industry, 36(6), 98-109. https://doi.org/10.3787/j. issn.1000-0976.2016.06.015

19. Lovy, O. I. (2016). Effects of Micro Finance Banks Liquidity on the Working Capital of Small and Medium Scale Enterprises. International Journal of Business \& Law Research, 4(24), 53-59. Retrieved from http://seahipaj. org/journals-ci/june-2016/IJBLR/ full/IJBLR-J-5-2016.pdf

20. Mandiefe, S. P. (2016). How Working Capital Affects the Profitability of Deposit money banks: Case of Afriland Cameroon. Arabian Journal of Business and Management Review, 6(46),1-9. Retrieved from https://www.omicsonline.org/ open-access/how-working-capitalaffects-the-profitability-of-commercial-banks-case-ofafrilandcameroon-2223-5833-1000261. php?aid $=82596$

21. Mbawuni, J., Mbawuni, M. H., \& Nimako, S. G. (2016). The Impact of Working Capital Management on Profitability of Petroleum Retail Firms: Empirical Evidence from Ghana. International Journal of Economics and Finance, 8(6), 49. http://dx.doi.org/10.5539/ijef. v8n6p49

22. Monaldi, F. (2015, September). The Impact of the Decline in Oil Prices on the Economics, Politics and Oil Industry of Venezuela. Columbia Center on Global Energy Policy Discussion Papers. Retrieved from http://energypolicy.columbia. edu/sites/default/files/Impact $\% 20$ of $\% 20$ the $\% 20$ Decline $\% 20 \mathrm{in} \% 20$ Oil\%20Prices\%20on\%20Venezuela_September\%202015.pdf
23. Myers, S. C., \& Majluf, N. S. (1984). Corporate Financing and Investment Decisions when Firms Have Information that Investors do Not Have. Journal of Financial Economics, 13(2), 187-221. https://doi.org/10.1016/0304405X(84)90023-0

24. Ogodor, B. N., \& Mukolu, M. O. (2015). Working Capital Adequacy and Organization Performance. The Case Study of Banks in Nigeria. Journal of Research in Humanities and Social Science, 3(10), 20-25. Retrieved from http://www.questjournals. org/jrhss/papers/vol3-issue10/ D3102025.pdf

25. Oloye, M. I., \& Osuma, G. (2015). Impacts of Mergers and Acquisition on the Performance of Nigerian Banks (A Case Study of Selected Banks). Pyrex Journal of Business and Finance Management Research, 1(4), 23-40. Retrieved from http://www.pyrexjournals. org/pjbfmr/pdf/2015/november/ oloye-and-osuma.pdf

26. Osabohien, R., Osabuohien, E., \& Urhie, E. (2018). Food Security, Institutional Framework and Technology: Examining the Nexus in Nigeria Using ARDL Approach. Current Nutrition \& Food Science, 14(2), 154-163. https://doi.org/10.2 174/1573401313666170525133853

27. Padachi, K., Howorth, C., \& Narasimhan, M. S. (2012).

Working Capital Financing Preferences: The Case of Mauritian Manufacturing Small and Medium-Sized Enterprises (SMEs). Asian Academy of Management Journal of Accounting and Finance, 8(1), 125-157.

Retrieved from http://web.usm. my/journal/aamjaf/vol\%208-12012/8-1-6.pdf

28. Pandey, I. M. (2010). Financial Management Tenth edition (pp. 648-649). New Delhi: Vikas Publishing House Pvt Ltd.

29. Poghosyan, T., \& Hesse, H. (2009). Oil prices and bank profitability: evidence from major oil-exporting countries in the Middle East and North 
Africa (IMF Working Papers, 9(WP/09/220), 1-22). https://doi. org/10.5089/9781451873672.001

30. Raheman, A., \& Nasr, M. (2007) Working capital management and profitability: Case of Pakistani firms. International Review of Business Research Papers, 3(1), 279-300.

31. Sharma, A. K., \& Kumar, S. (2011). Effect of Working Capital Management on Firm Profitability. Global Business Review, 12(1), 159-173.

32. Shin, H. H., \& Soenen, L. (1998). Efficiency of Working Capital and Corporate Profitability. Financial Practice and Education, 8(1), 37-45.

33. Smith, K. (1980). Profitability Versus Liquidity Tradeoffs in Working Capital Management, in readings on the Management of Working
Capital. In K. V. Smith, (Ed.). St. Paul: West Publishing Company.

34. Sogorb-Mira, F. (2005). How SME uniqueness affects capital structure: Evidence from a 1994-1998 Spanish data panel. Small Business Economics, 25(5), 447-457. http:// dx.doi.org/10.1007/s11187-0046486-8

35. Soludo, C. C. (2004).

Consolidating the Nigerian banking industry to meet the development challenges of the 21 st century. In Being an address delivered to the Special Meeting of the Bankers Committee, held on July (Vol. 6).

36. Umoren, A., \& Udo, E. (2015). Working Capital Management and the Performance of Selected Deposit Money Banks in Nigeria. British Journal of Economics, Management, and Trade, 7(1),
23-31. https://doi.org/10.9734/ BJEMT/2015/15132

37. Van-Horne, J. C., \& Wachowicz, J. M. (2004). Fundamentals of Financial Management (12 ${ }^{\text {th }}$ ed). New York: Prentice Hall Publishers.

38. Yahaya, A., \& Bala, H. (2015). Working Capital Management and Financial Performance of Deposit Money Banks. Research Journal of Finance and Accounting, 6(16), 5771. Retrieved from http://iiste.org/ Journals/index.php/RJFA/article/ view/24976

39. Yeboah, B., \& Yeboah, M. (2014). The Effect of Working Capital Management of Ghana Banks on Profitability: Panel Approach. International Journal of Business and Social Science, 5(10), 294-306. Retrieved from http://ijbssnet. com/journals/Vol_5_No_10_September_2014/37.pdf 